\title{
Condition, feeding and reproductive potential of white seabream Diplodus sargus as indicators of habitat quality and the effect of reserve protection in the northwestern Mediterranean
}

\author{
Josep Lloret*, Serge Planes \\ Ecole Pratique des Hautes Etudes - ESA CNRS 8046, Centre de Biologie et d'Ecologie Tropicale et Méditerranéenne, \\ Campus Universitat de Perpignan, 52 Ave. Villeneuve, 66860 Perpignan Cedex, Languedoc-Roussillon, France
}

\begin{abstract}
Individuals of white seabream Diplodus sargus collected from rocky and sandy coastal areas in the northwestern Mediterranean were examined to evaluate habitat influences on their condition, feeding and reproductive potential. To determine the potential effectiveness of a marine protected area, we quantified the consequences of the Marine Reserve of Banyuls-Cerbère (situated on the rocky coast) on condition, feeding and reproduction. Measures of condition (weight at length, liver size and lipid content in muscle and liver), feeding potential (digestive tract weight) and reproductive potential (gonad weight) were compared between substrate type, bathymetric zone, level of protection, sexes and maturity stages. The study reveals differences in the condition of white seabream between adjacent habitats. During the juvenile phase, fish condition was generally higher in the unprotected rocky coast than in the unprotected sandy coast. In addition, post-spawners were better conditioned within the rocky areas of the reserve than in adjacent unprotected rocky areas. At the Banyuls-Cerbère Marine Reserve, the reproductive potential of male spawners decreased with depth, but the condition of spawners followed the opposite trend. However, we did not find any significant effect of protection on feeding or reproductive potential. With the exception of the liver index, condition did not differ significantly between sexes and maturity stages. For a given body weight, livers of female spawners were significantly bigger than those of male spawners and postspawners. In addition, feeding potential of post-spawners was better than that of spawners. Condition indices were independent of fish size, but there was a positive relationship between the reproductive potential and length of male spawners. Because condition is presumed important to growth, survival and recruitment, and because reproductive potential is presumed important to recruitment, we hypothesize that: (1) unprotected rocky areas may potentially contribute more to production of white seabream than the unprotected sandy coasts and are therefore, potential essential fish habitats for this species; and (2) the marine reserve might offer increased production for white seabream, providing long-term benefits to the local fishery of this species.
\end{abstract}

KEY WORDS: Diplodus sargus · Marine protected areas · Rocky coasts · Sandy coasts · Fish condition $\cdot$ Reproductive potential $\cdot$ Feeding potential

\section{INTRODUCTION}

Despite evidence of important ecological linkages between habitat and fishery production, the management of most commercial resources worldwide has his- torically concentrated on assessing stock size and controlling fishing mortality (Benaka 1999). However, the conservation and management of fishery habitat is becoming a promising fishery management tool (Fogarty 1999, Minello 1999). Accordingly, a key ele- 
ment in moving toward sustainable fisheries is the identification of essential fish habitats (EFHs), i.e. high quality habitats for fishery species (Benaka 1999). Many studies have addressed the role of key habitats and associated ecological communities in coastal waters and estuaries (such as seagrass beds and rockyalgal reefs) as essential spawning and nursery habitats for commercial and recreational marine species (e.g. Able 1999, Minello 1999, Packer \& Hoff 1999). In addition, inshore soft bottoms along the coast serve as nurseries for many demersal species (Dalley \& Anderson 1997, Bertrand et al. 1999), where some ecological processes that enhance their survivorship take place (Kaiser et al. 1999). Hence, much of the essential marine fish habitat of concern is in shallow coastal waters and estuarine wetlands, even though some deep habitats may constitute natural refuges for large individuals of some demersal species (Yoklavich et al. 1999).

Marine reserves, areas closed to or with very limited harvesting, are being used increasingly to conserve exploited populations and fisheries. It has been demonstrated that abundance, mean size of individuals and spawning biomass of exploited populations tend to be greater inside reserves than in comparable areas subject to intense harvesting (reviewed by Roberts \& Polunin 1991, Guénette et al. 1998). Most investigations on EFHs and marine protected areas have studied differences of abundance, biomass or fish sizes to evaluate habitat effects on fish populations, but very few used ecophysiological parameters (e.g. Rowe 2002). Thus, little is known on the effect of habitat structure and protection on fish condition.

Although there is substantial research on fish species in Mediterranean coastal waters and the effect of reserve protection on abundance, biomass and fish size (e.g. García-Rubíes \& Zabala 1990, Dufour et al. 1995, Francour 1997, Planes et al. 2000, GarcíaCharton \& Pérez-Ruzafa 2001), there are few studies on the effects of the bottom type on fish species (e.g. García-Rubíes \& Macpherson 1995, Harmelin-Vivien et al. 1995, Guidetti 2000). Despite evidence of the importance of the function of habitat for marine fish physiology, condition has seldom been used to assess small-scale habitat quality in marine ecosystems, where most research on essential fish habitats and the effects of marine protected areas dealt with differences in abundance and biomass between habitats (Roberts \& Polunin 1991, Benaka 1999). As such, fish condition will be used in this study as an indicator of habitat quality. The northwestern Mediterranean contains several declining coastal habitats, such as seagrass beds, rocky bottoms, soft bottoms and wetlands. Rocky shores represent more than half of the Mediterranean coasts and consist of many ecologically important and diverse microhabitats (Ros et al. 1985). Their conservation may be important to maintain healthy fisheries of some species in the area.

The purpose of this paper is to examine variation in 3 population parameters (condition, feeding and reproductive potential) of the white seabream Diplodus sargus as indicators of habitat quality in the northwestern Mediterranean. Specifically, we aim to explore the impact of reserve protection, substrate type and depth on condition, feeding and reproductive potential to evaluate the effectiveness of a marine reserve and the importance of certain types of substrates. We hypothesize that bottom type, protection and depth might be important for condition. The effect of sex, maturity and length on condition will be also analyzed because these biological parameters have been shown to affect condition of many fish species (see Shulman \& Love 1999).

The condition of a fish is affected by interactions among habitat characteristics (e.g. food and habitat availability, competition, physical factors, parasitic infections and pollution) and the physiology of the fish (Chellappa et al. 1989, Kerrigan 1994, Griffiths \& Kirkwood 1995, Parrish \& Mallicoate 1995, Guderley et al. 1996, Francis 1997, Lee \& Khan 2000, Lloret \& Rätz 2000, Yaragina \& Marshall 2000). As a measure of energy reserves, condition indices can have major consequences for the health of individual fish and influence survival and population success (Kjesbu et al. 1992, Lambert \& Dutil 1997, Marshall \& Frank 1999, Shulman \& Love 1999). Inadequate energy reserves have been implicated in the reduced reproductive potential of several fish species through reduced fecundity and/or quality of eggs and larvae (Kjesbu et al. 1992, Adams 1999, Marshall et al. 1999, Lambert \& Dutil 2000). Poor condition (i.e. lower available energy reserves) may also lower the chances of survival of big fish, leading to an increase of natural mortality (Krivobok \& Tokareva 1972, Love 1974, Adams 1999, Shulman \& Love 1999). Starvation due to exhaustion of energy reserves, particularly in smaller individuals and during the nonfeeding periods, weakens fish and also renders them more susceptible to predation and to a variety of environmental stressors (e.g. parasites, thermal and contaminant effects).

The condition of a fish can be assessed by a variety of criteria ranging from morphometric to physiological and biochemical (e.g. lipid content) measurements. Lipids play a critical role in the health of benthic and planktonic animals and plants (Adams 1999). They are known to play a role as energy reserves (especially during nonfeeding periods) and as regulators of body density, cellular metabolism, detoxification, behavior (swimming performance and migration) and reproduction (Planes et al. 1997, Adams 1999, Shulman \& Love 
1999, Morris \& Culkin 2000). They display wide variability and thus, possess great potential as 'markers' of condition. Lipids are a principal energy reserve in teleosts and are often the first components to be mobilized during periods of stress. As energy reserves strongly affect spawning and egg quality of many fish species, a deficiency negatively affects fecundity, fertilization rate and hatching rate of many of them (Adams 1999, Rainuzzo et al. 1997). Lipids influence fish reproductive potential not only through gonad development and maturation but also through viability of the progeny (Adams 1999). This paper investigates the use of morphometric, physiological and biochemical condition indices as measures of habitat quality for the potential production of white seabream in the northwestern Mediterranean.

\section{MATERIALS AND METHODS}

Sampling. We collected individuals of white seabream from 3 different adjacent areas in the Gulf of Lions (northwestern Mediterranean; Fig. 1): a rocky protected area (Banyuls-Cerbère Marine Reserve); a rocky unprotected area (south of the Marine Reserve until Cape Creus and north to Cape Béar); and a sandy unprotected habitat (sandy coast north of Cape Béar to

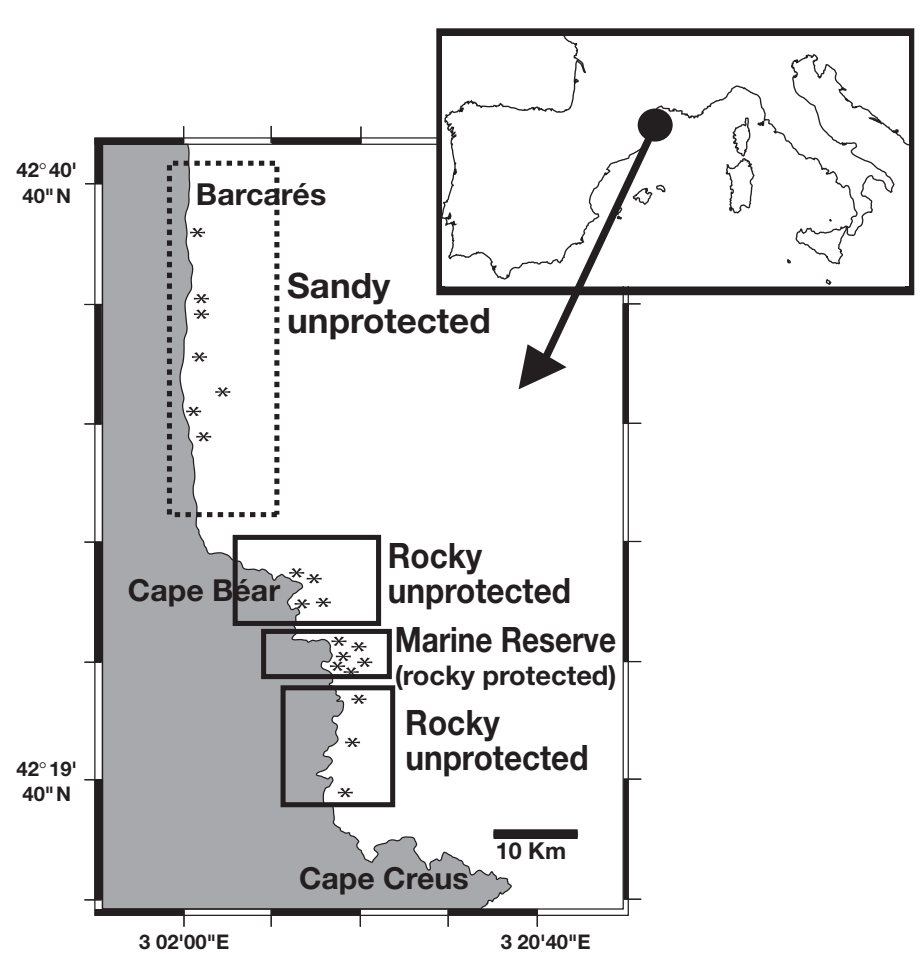

Fig. 1. Habitats where the white seabream was sampled between mid-April and August 2001. *: sampling station
Barcarés). Sandy reserve sites were not included in the study because they do not exist within the area of study. All these areas have a similar hydrological regime. The large freshwater input in the area comes mainly from the Rhône River, whose mouth is situated about $150 \mathrm{~km}$ north of the study area. In addition, there is little freshwater discharge in the sandy area, which comes from small, local, rivers. There is a major current flowing southwards and drawing continental waters from the Rhône river. Intense water mixing is induced by the predominant strong, dry and cold northwesterly winds blowing in the study area. The Banyuls-Cerbère Marine Reserve was established in 1974 and protects 650 ha along $6.5 \mathrm{~km}$ of rocky coast. Professional artisanal fishing is allowed in part of the marine reserve, even though the fishing effort is limited to a number of boats. This reserve protects the abundance of several fish species, including the white seabream (Dufour et al. 1995). The sandy bottom sampled represents the southern part of the wide sandy coast of the Gulf of Lions, where rocks are only found in patches along the continental platform or in the form of isolated capes and ports.

The white seabream is a Mediterranean fishery species that inhabits shallow rocky and seabed bottoms. Together with other species of the genus Diplodus, it dominates fish assemblages in shallow rocky habitats (Sala \& Ballesteros 1997). It is a protandrous hermaphroditic fish that reproduces from March to June in the western Mediterranean (Bauchot \& Hureau 1986). However, males and females have been observed which probably never undergo sex reversal. The white seabream is mainly caught by the local artisanal fishery and constitutes a valuable fishery resource because of its high price on the market. Although different aspects of its biology have been studied, e.g. settlement (García-Rubíes \& Macpherson 1995, Harmelin-Vivien et al. 1995), growth (Gordoa \& Molí 1997), reproduction (Micale et al. 1987) and feeding (Rosecchi 1985, Sala \& Ballesteros 1997), studies of condition are scarce (Man-Wai \& Quignard 1984, Martínez-Pastor \& Villegas-Cuadros 1996, Planes et al. 1997). D. sargus was selected because it is abundant in the littoral bottoms of the northwestern Mediterranean and because it is found within a limited depth interval $(0$ to $70 \mathrm{~m})$. The fish were caught during a period of the spawning season (end of April to end of May), when fish were in the same maturity stage as well as during the post-spawning season (July to August) in 2001. The sampling covered the overall bathymetric distribution of white seabream from 0 to $70 \mathrm{~m}$ depth. Two bathymetric zones were established: shallow (0 to $10 \mathrm{~m}$ depth) and deep (10 to $70 \mathrm{~m}$ depth). To obtain fish samples from the shallow zones of the different areas, we undertook spear fishing at night. To obtain fish sam- 
ples from the deep zones of the different areas, we trawled during daytime on board RV 'Nereïs' (CNRS, France) and also collected samples $(n=20)$ from commercial gill-netters and trawlers fishing during night and daytime. Mesh sizes of trawl and gillnets varied between 20 and $40 \mathrm{~mm}$. Because we avoided trawling within the marine reserve, trawls performed at the deepest limit of the reserve were considered representative of this habitat (i.e. samples from these trawls were assigned to the deep rocky protected habitat). Samples from the sandy habitat were captured in the vicinity of rocks dispersed along the sandy coast.

In the laboratory, the total length of fish was measured to the nearest $0.5 \mathrm{~cm}$ and their body weight to the nearest $1 \mathrm{mg}$. Sex and reproductive status were determined by visual inspection of the gonads. Fish were identified as belonging to 1 of 5 demographic groups: juveniles, spawning males, spawning females, post-spawning males and post-spawning females. Adult fish were dissected and eviscerated, and the carcass, liver and gonads were weighed to the nearest $1 \mathrm{mg}$. We also measured weights of digestive tracts including food contents (to the nearest $1 \mathrm{mg}$ ) from adult fishes caught by spear fishing in the shallow zone of the protected and unprotected rocky coasts by removing and weighing them to the nearest $1 \mathrm{mg}$. We did not consider digestive tracts of fish from the deep zones or sandy areas for 2 reasons: (1) to avoid the effect of time of capture (samples in the deep zone were caught during both night and daytime); and (2) to circumvent confounding effects of prey composition. While the most important prey types identified macroscopically for fish from shallow rocky waters were algae and animals with hard parts such as bivalves, sea urchins and barnacles, a mixture of soft and digested preys predominated in specimens caught in deep and sandy areas. We did not weigh the livers and digestive tracts of juvenile fish in order to avoid errors of precision, due to their small size. From each juvenile and adult fish, 1 small sample ( 2 to $5 \mathrm{~g}$ ) of liver and muscle was taken. Muscle samples from adult fish were taken dorsally directly under the anterior dorsal fin and well above the lateral line, while those of juveniles were taken from the tail to the eye. After tissue samples were cleaned of skin, scales and bones, they were immediately frozen at $-30^{\circ} \mathrm{C}$ for total lipid analysis ashore.

Condition analyses and evaluation of reproductive and feeding potential. We used here several condition indicators based on weight-length data, liver sizes and lipid content. Integration of the information provided by different condition indices should reflect the overall physiological history of the fish. Since the specific methodologies for the physiological and biochemical measure of condition involve only organs and tissues at an individual level, they may not reveal the overall pattern of a population or group. We therefore analyzed data based on the average condition of relatively large numbers of fish rather than a few individuals (Shulman \& Love 1999, Morris \& Culkin 2000). In total, we collected 347 individuals. To determine fish condition, we computed for each single adult fish $(n=155)$ several condition indices. First, the Fulton's $\mathrm{K}$ condition factor was calculated with the formula $\mathrm{K}=100\left(W / L^{3}\right)$, where $W$ is the eviscerated wet body weight and $L$ is the total length. The stated formula, with the constant equal 3, assumes an isometric growth in fish (i.e. the $\beta$-value of the weightlength relationship must be close to 3 (Bolger \& Connolly 1989, Cone 1989). This morphometric index assumes that heavier fish of a given length are in better condition and therefore is a simple indicator of energy storage. Second, a liver index (hepatosomatic index, HSI) was computed as a proxy for energy reserves stored in this organ. The HSI was calculated as HSI $=100(L W / W)$, where $L W$ and $W$ represent liver and somatic (eviscerated) wet weights, respectively. Third, determination of total lipid was carried out in the laboratory from muscle $(\mathrm{n}=347)$ and liver $(\mathrm{n}=347)$ samples of both juveniles and adults. The frozen muscle and liver samples were first minced and mixed using an electrical mincer. From these mixtures, portions were taken for the determination of lipid content and dry weight. Dry weights were determined after lyophilization and lipids were extracted with a 2:1 chloroform/methanol mixture (Folch et al. 1957) after homogenization of dry matter in $1 \mathrm{M}$ sodium hydroxide $(\mathrm{NaOH})$. Total lipids were determined spectrophotometrically with the sulphophosphovanillin method (Barnes \& Blackstock 1973), a colorimetric method that depends on the reaction of lipids with sulfuric acid, phosphoric acid and vanillin to give a red complex. The standard solution is prepared by dissolving $80 \mathrm{mg}$ of cholesterol in $100 \mathrm{ml}$ of 2:1 chloroform/methanol (this assumes that $800 \mu \mathrm{g}$ cholesterol give the same color as $1000 \mu \mathrm{g}$ total lipids). Although this assumption was specifically designed for the estimation of total lipids in human serum, it is applicable to tissues of many marine animals (Barnes \& Blackstock 1973). However, lipid levels determined under this assumption are not totally exact. The optical density was read at $520 \mathrm{~nm}$ on a spectrophotometer. Physiological measures such as the HSI and biochemical measures such as lipid content (both used in this study) are accurate measures of the energy reserves of fish (Adams 1999, Shulman \& Love 1999). Apart from these condition indices, we also computed a gonadosomatic index (GSI) for spawners $(\mathrm{n}=94)$ and a digestivosomatic index (DSI) for spawners and post-spawners $(\mathrm{n}=155)$ as indica- 
tors of food intake and gametic effort, respectively (Okuda 2001). We considered these indices to be rough measures of reproductive and feeding potential, even though there exist more exact, complex methods to analyze the reproductive and feeding potential of fish (e.g. studies on fecundity and diet). The GSI and DSI were calculated as GSI $=100$ $(\mathrm{GW} / \mathrm{W})$ and DSI = 100 (DW/W), where GW, DW and W represent gonad, digestive tract (including food contents) and somatic (eviscerated) wet weights, respectively. We first analyzed the physiological effects (i.e. influence of length, sex and maturity) on condition, DSI and GSI, by pooling all samples from all habitats and thereafter, we analyzed the habitat effect taking into account the physiological effects.

Statistical analyses. We used analyses of variance (ANOVA) models to compare condition, reproductive and feeding indices among habitats, sexes and maturity stages. We used analysis of covariance (ANCOVA) to assess whether length (covariate) accounted for the change in these indices across habitats. We could not include all independent factors in a single multiple ANOVA model because our data were unbalanced (e.g. no juveniles and adult post-spawners were caught in the deep zones). Full factorial design was not possible due to absence of sandy areas in the reserve. Certain analyses were limited to within a level of the other factor in order to keep them balanced (e.g. substrate type was only compared for unprotected areas due to the lack of sandy protected sites). The assumptions of normality and homogeneity of variances were tested with the Kolmogorov-Smirnov and the Cochran's tests, respectively. If these assumptions were not met, data were log-transformed. Arc-sine transformation of lipid percentages was also considered if logarithmic

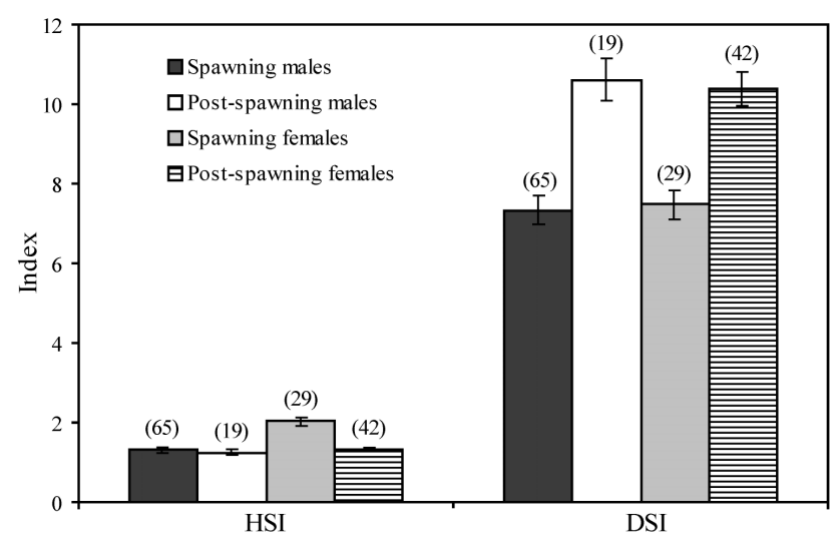

Fig. 2. Differences in hepatosomatic index (HSI) and digestivosomatic index (DSI) between sexes and reproductive status of white seabream (samples from all habitats together). Means are indicated with the SE. No. of samples given in brackets transformation did not solve the heterogeneity (Underwood 1998). If data were not distributed normally or variances were heterogeneous after transformations, we used a non-parametric Kruskal-Wallis ANOVA. For ANCOVA models, we furthermore tested the homogeneity of regressions (or slopes) among groups with the test of parallelism. Tukey's honest significant difference (HSD) test was used for post hoc comparisons of significant effects after ANOVA or ANCOVA (when more than 2 groups were compared). A p-value of 0.05 or less was considered statistically significant, but we disregarded any group (sex, maturity or habitat) containing less than 10 samples for the analyses. Statistical analyses were conducted with Statistica (Statsoft 1999).

\section{RESULTS}

\section{Distribution of fish by sex, reproductive status, length and habitat}

Although we sampled the overall bathymetric distribution of white seabream, juveniles and post-spawners were caught exclusively in the shallow zones $(0$ to $10 \mathrm{~m})$, while spawners were caught from 0 to $70 \mathrm{~m}$ depth. Adults represented the 37,41 and 53\% of all fish caught in sandy unprotected, rocky unprotected and rocky protected areas, respectively. Mean sizes of adult fish captured in these respective areas were $25.6 \pm 3.5(\mathrm{n}=27), 25.4 \pm 3.3(\mathrm{n}=58)$ and $27.7 \pm 4.2 \mathrm{~cm}$ $(\mathrm{n}=70)$, while those of juveniles were respectively $14.6 \pm 3.8(\mathrm{n}=46), 16.2 \pm 4.1(\mathrm{n}=84)$ and $16.3 \pm 3.8 \mathrm{~cm}$ ( $\mathrm{n}=62$ ). In total, we collected 192 juveniles between 8 and $24 \mathrm{~cm}, 84$ adult males between 20 and $39.5 \mathrm{~cm}$, and 71 adult females between 19 and $35 \mathrm{~cm}$.

\section{Effect of length, sex and maturity on condition, feeding and reproductive potential}

The condition factor, $K$, and the lipid percentage in muscle and liver did not differ significantly among sexes and reproductive stages. In contrast, there were sexual and reproductive effects on HSI and DSI values. Mean HSI of female spawners was significantly greater than male spawners and post-spawners of both sexes (Table 1, Fig. 2). Female and male spawners had a lower mean DSI than post-spawners (Table 1, Fig. 2). Condition was independent of fish size, as no significant correlations $(\mathrm{p}>0.05)$ were observed between values of any condition index (K, HSI, lipid in muscle and lipid in liver) and length (the covariate) for any sex or reproductive stage (Table 1). The ANCOVA analysis of GSI showed that interaction between sex, maturity 
Table 1. Diplodus sargus. Summary of results from analysis of covariance (ANCOVA) and post hoc Tukey's honest significant difference (HSD) test evaluating the effect of fish length (covariate), sex and reproductive status on the indices studied. Sex and reproductive status are combined into a single categorical factor (Sexmat) which includes the following demographic groups: spawning males (SM), spawning females (SF), post-spawning males (PM), post-spawning females (PF) and juveniles (J). HSA: hepatosomatic index; DSI: digestivosomatic index; GSI: gonadosomatic index

\begin{tabular}{|c|c|c|c|c|c|}
\hline Index & Effect (groups) & df & $F$ & $\mathrm{p}$ & HSD \\
\hline \multirow[t]{3}{*}{$\mathrm{K}$} & Sexmat (SM, SF, PM, PF) & 3 & 0.248 & 0.862 & \\
\hline & Length & 1 & 0.002 & 0.965 & \\
\hline & Sexmat $\times$ Length & 3 & 2.000 & 0.117 & \\
\hline \multirow[t]{3}{*}{ HSI } & Sexmat (SM, SF, PM, PF) & 3 & 41.053 & $<0.001$ & \multirow[t]{3}{*}{$\mathrm{SF}>\mathrm{SM}=\mathrm{PF}=\mathrm{PM}$} \\
\hline & Length & 1 & 2.009 & 0.158 & \\
\hline & Sexmat $\times$ Length & 3 & 0.875 & 0.456 & \\
\hline \multirow[t]{3}{*}{ Muscle lipid } & Sexmat (J, SM, SF, PM, PF) & 4 & 1.362 & 0.246 & \\
\hline & Length & 1 & 0.382 & 0.537 & \\
\hline & Sexmat $\times$ Length & 4 & 1.106 & 0.353 & \\
\hline \multirow[t]{3}{*}{ Liver lipid } & Sexmat (J, SM, SF, PM, PF) & 4 & 1.007 & 0.404 & \\
\hline & Length & 1 & 0.009 & 0.926 & \\
\hline & Sexmat $\times$ Length & 4 & 2.198 & 0.070 & \\
\hline \multirow[t]{3}{*}{ DSI } & Sexmat (SM, SF, PM, PF) & 3 & 13.878 & 0.000 & \multirow[t]{3}{*}{$\mathrm{PM}=\mathrm{PF}>\mathrm{SM}=\mathrm{SF}$} \\
\hline & Length & 1 & 0.931 & 0.337 & \\
\hline & Sexmat $\times$ Length & 3 & 1.055 & 0.372 & \\
\hline \multirow[t]{3}{*}{ GSI } & Sexmat (SM, SF) & 1 & 1.069 & 0.309 & \\
\hline & Length & 1 & 22.264 & $<0.001$ & \\
\hline & Sexmat $\times$ Length & 1 & 6.543 & 0.012 & \\
\hline
\end{tabular}

and length was significant (Table 1). There was a positive significant $(\mathrm{p}<0.05)$ relationship between GSI and length (covariate) of male spawners (Table 1, Fig. 3), but not for female spawners ( $>$ > 0.05). No significant $(p>0.05)$ relationship between condition indices (K, HSI and lipid content) and DSI or GSI existed. While Fulton's K of adult fish varied between

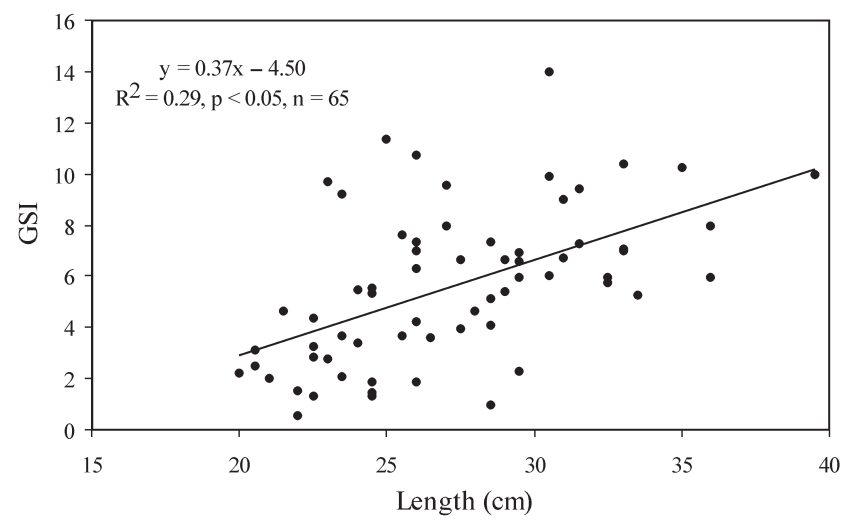

Fig. 3. Diplodus sargus. Linear relationship between gonadosomatic index (GSI) and length of male spawners in spring 2001 (samples from all habitats together)
1.427 and $2.425(\mathrm{n}=155)$, HSI of adults varied between 0.682 and $2.944(\mathrm{n}=155)$, and DSI between 0.046 and $10.683(\mathrm{n}=155)$. GSI values of male spawners ranged from a minimum of 0.549 to a maximum of 13.973 ( $\mathrm{n}=$ 65), while those of female spawners ranged from a minimum of 1.867 to a maximum of $8.430(\mathrm{n}=29)$. Lipid constituted only 0.46 to $15.46 \%$ ( $\mathrm{n}=347$ ) and 0.11 to $7.38 \%(n=347)$ of the dry liver and muscle of combined adult and juvenile white seabream, respectively. The underlying assumption of an isometric growth associated with the use of Fulton's condition factor was respected $(\beta$-coefficient $=3.02)$.

\section{Effect of habitat and protection on condition, feeding and reproductive potential}

We examined the habitat effect on juveniles, spawners and post-spawners separately to consider the effects of sex, maturity and length on the different indices, and to account for the limitations posed by the data (unbalanced design). Because of sexual differences in the HSI during spawning and because there was an effect of length on the GSI of male spawners, we examined females and males separately to assess 
differences in HSI and GSI between habitats. For the rest of indices, we pooled data on male and female spawners together. Because differences in condition between sexes were not observed after spawning, we pooled condition data of male and female postspawners for the analysis of protection effects on postspawners.

\section{Juveniles}

Juveniles from unprotected rocky habitats showed a higher percentage of lipid in the muscle and the liver compared to juveniles from the sandy unprotected habitat, with a 90 to $100 \%$ increase in lipid concentration (Table 2, Fig. 4). However, lipids of juvenile fish in protected and unprotected rocky habitats were not significantly different from one another $(p>0.05)$.

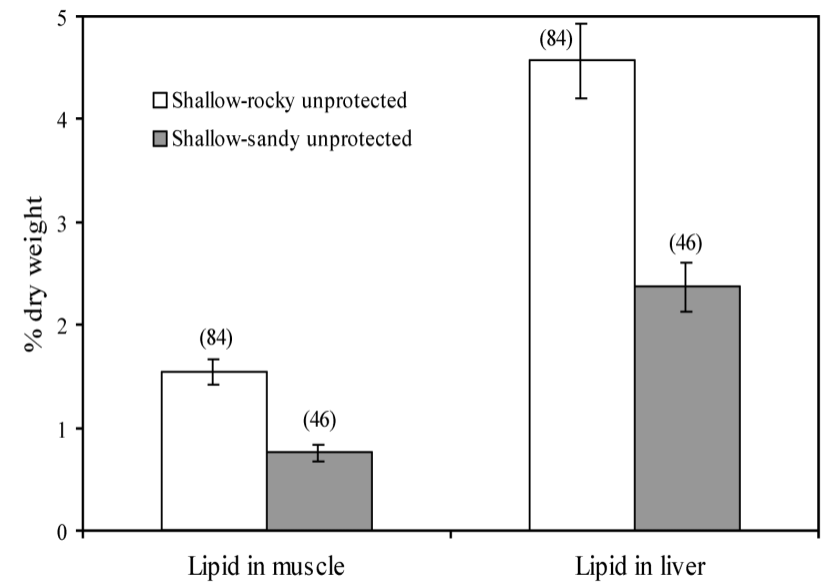

Fig. 4. Diplodus sargus. Differences in lipid content in muscle and liver of juvenile white seabream between the unprotected, shallow zones of rocky and sandy habitats. Means are indicated with the SE. No. of samples given in brackets

Table 2. Diplodus sargus. Summary of results from analysis of variance (ANOVA and Kruskal-Wallis ANOVA) and covariance (ANCOVA) evaluating the effect of bottom type, depth zone and protection on indices for each maturity stage (juveniles, spawners and post-spawners). The following habitats are considered: rocky unprotected (RUP), rocky protected (RP) and sandy unprotected (SUP). The letter 'a' stands for the shallow zone (0 to $10 \mathrm{~m}$ depth) and 'b' for the deep zone (10 to $70 \mathrm{~m}$ depth). SM and SF indicate spawning males and females, respectively. The effect of habitat (bottom type, protection and depth zone) is tested for each index separately and keeping analyses balanced (in certain cases analyses were limited to specific habitats which are shown in brackets). Length and sex are included in the analyses when they are significant after results presented in Table 1. HSI: hepatosomatic index; DSI: digestivosomatic index; GSI: gonadosomatic index

\begin{tabular}{|c|c|c|c|c|c|c|c|}
\hline Maturity stage & Index & Test & Effect (groups) & df & $F$ & Chi-square & $\mathrm{p}$ \\
\hline \multirow[t]{4}{*}{ Juveniles } & \multirow[t]{2}{*}{ Muscle lipid } & Kruskal-Wallis & Bottom type (RUPa, SUPa) & 1 & & 7.870 & 0.005 \\
\hline & & Kruskal-Wallis & Protection (RUPa, RPa) & 1 & & 0.000 & 1.000 \\
\hline & \multirow[t]{2}{*}{ Liver lipid } & ANOVA & Bottom type (RUPa, SUPa) & 1 & 28.683 & & $<0.001$ \\
\hline & & ANOVA & Protection (RUPa, RPa) & 1 & 3.070 & & 0.082 \\
\hline \multirow[t]{19}{*}{ Spawners } & \multirow[t]{2}{*}{ K } & ANOVA & Protection (RUPa, RPa) & 1 & 0.077 & & 0.783 \\
\hline & & ANOVA & Depth zone (RPa, RPb) & 1 & 0.131 & & 0.719 \\
\hline & \multirow[t]{6}{*}{ HSI } & \multirow[t]{3}{*}{ ANOVA } & Sex (SF, SM) & 1 & 53.935 & & $<0.001$ \\
\hline & & & Protection (RUPa, RPa) & 1 & 0.033 & & 0.856 \\
\hline & & & Sex $\times$ Protection & 1 & 1.671 & & 0.204 \\
\hline & & \multirow[t]{3}{*}{ ANOVA } & Sex (SF, SM) & 1 & 15.644 & & $<0.001$ \\
\hline & & & Depth zone (RPa, RPb) & 1 & 0.159 & & 0.692 \\
\hline & & & Sex $\times$ Depth zone & 1 & 0.107 & & 0.745 \\
\hline & \multirow[t]{2}{*}{ Muscle lipid } & ANOVA & Protection (RUPa, RPa) & 1 & 0.076 & & 0.783 \\
\hline & & ANOVA & Depth zone (RPa, RPb) & 1 & 7.333 & & 0.009 \\
\hline & \multirow[t]{2}{*}{ Liver lipid } & ANOVA & Protection (RUPa, RPa) & 1 & 1.020 & & 0.319 \\
\hline & & ANOVA & Depth zone (RPa, RPb) & 1 & 1.456 & & 0.233 \\
\hline & DSI & ANOVA & Protection (RUPa, RPa) & 1 & 0.026 & & 0.873 \\
\hline & \multirow[t]{3}{*}{ GSI males } & \multirow[t]{3}{*}{ ANCOVA } & Depth zone (RPa, RPb) & 1 & 8.969 & & 0.005 \\
\hline & & & Length & 1 & 6.643 & & 0.010 \\
\hline & & & Length $\times$ Depth zone & 1 & 0.045 & & 0.831 \\
\hline & \multirow[t]{3}{*}{ GSI females } & \multirow[t]{3}{*}{ ANCOVA } & Protection (RPa, RUPa) & 1 & 0.378 & & 0.544 \\
\hline & & & Length & 1 & 3.852 & & 0.062 \\
\hline & & & Protection $\times$ Length & 1 & 4.898 & & 0.060 \\
\hline \multirow[t]{5}{*}{ Post-spawners } & $\mathrm{K}$ & ANOVA & Protection (RPa, RUPa) & 1 & 0.479 & & 0.491 \\
\hline & HSI & ANOVA & Protection (RPa, RUPa) & 1 & 16.426 & & $<0.001$ \\
\hline & Muscle lipid & ANOVA & Protection (RPa, RUPa) & 1 & 5.559 & & 0.022 \\
\hline & Liver lipid & ANOVA & Protection (RPa, RUPa) & 1 & 0.012 & & 0.913 \\
\hline & DSI & ANOVA & Protection (RPa, RUPa) & 1 & 0.122 & & 0.728 \\
\hline
\end{tabular}




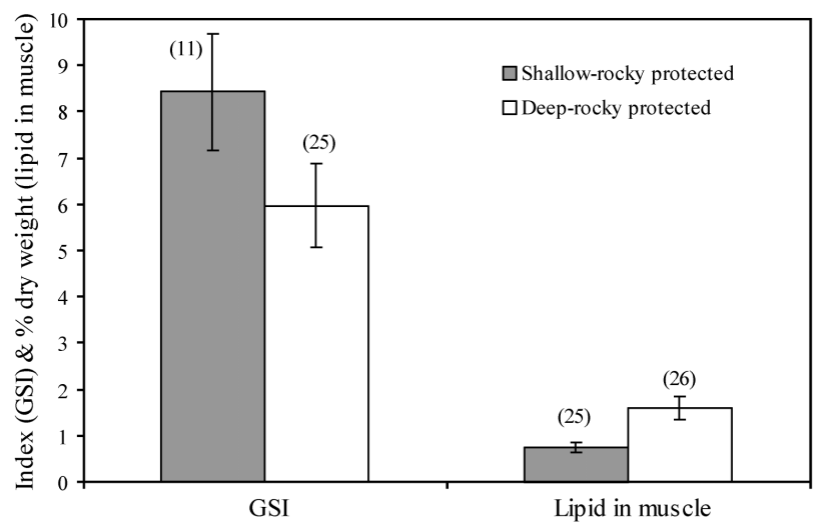

Fig. 5. Diplodus sargus. Differences in gonadosomatic index (GSI) of male spawners and differences in muscle lipid content of spawners of white seabream between the shallow and the deep zones of the rocky protected area. The adjusted GSI means (computed from the observed means after removing the effect of fish length) and the mean lipid content are indicated together with the SE. No. of samples given in brackets

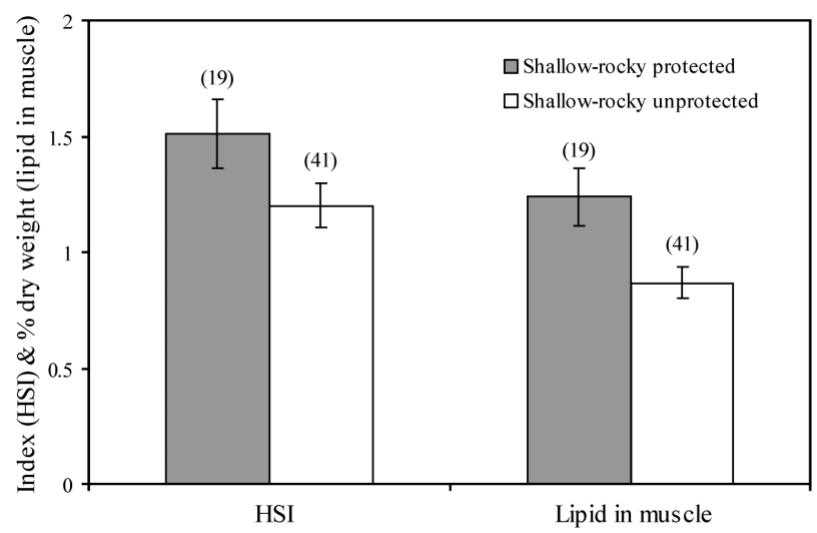

Fig. 6. Diplodus sargus. Differences in hepatosomatic index (HSI) and muscle lipid content of post-spawners of white seabream between the shallow zones of rocky protected and rocky unprotected areas. Means are indicated with the SE. No. of samples given in brackets

\section{Spawners}

We found a significant effect of depth on the lipid content in the muscle of spawners and the GSI of male spawners. The lipid content in muscle of spawners from the deep zones of the marine reserve was higher than the lipid content in muscle of spawners from the shallow areas of the reserve (Table 2, Fig. 5). In contrast to this, the mean GSI of male spawners caught in the shallow zone of the reserve was significantly higher than GSI values of males captured in the deep zone of the reserve (Table 2, Fig. 5). We did not find, however, any effect of protection on the GSI of female spawners (Table 2). Moreover, we did not find any significant effect of bottom type and protection on Fulton's K, HSI, DSI or lipid content (in muscle or liver) of spawners (Table 2).

\section{Post-spawners}

We found a significant effect of reserve protection on muscle lipid levels and the HSI of post-spawners (Table 2). Higher muscle lipid levels were detected in post-spawners in the shallow rocky protected area compared to the shallow rocky unprotected area (Fig. 6). The mean lipid content of muscle in postspawners was $1.24 \pm 0.16 \%$ for individuals caught in the protected rocky area and $0.87 \pm 0.11 \%$ for individuals caught in the unprotected rocky area. The same trend was detected for the HSI. A $30 \%$ increase in the HSI existed between post-spawners from protected and unprotected rocky areas (Fig. 6). However, we did not find any significant effect of protection on Fulton's $\mathrm{K}$, liver lipid levels and DSI (Table 2).

\section{DISCUSSION}

Our investigation shows that the condition and the reproductive potential of white seabream vary spatially in the northwestern Mediterranean. In general, there were significant differences in condition between the specimens caught in different habitats, even though not all condition indices, sexes or maturity stages had spatial patterns. However, for those that did vary spatially, condition indices showed the same pattern: within the unprotected shallow areas, they are higher in the rocky than the sandy habitat; within the rocky shallow habitat, they are higher in protected than unprotected areas. We found that the best conditioned juveniles of Diplodus sargus are those obtained from the rocky habitats. There they possess the highest concentration of lipid in their muscle and livers. For the rocky coast, even the small percentage of lipids found in the musculature or the liver of juveniles is larger than that in sandy habitats. The rocky habitat might provide a better environment in terms of food, predation risk or energy expenditure (the rate of energy expenditure may be less in the sheltered rocky sites). Similar trends have been reported for cod in the North Atlantic. According to Love (1974), cod from areas where the sea-bed is stony are almost always in good condition, while those from soft, sandy or muddy bottoms are in a poor condition. Recent studies have shown that different populations in freshwater and marine ecosystems display different levels of condition according to the characteristics of their habitats (Grecay \& Targett 1996, De Silva et al. 1998, FitzGer- 
ald et al. 1998, Chouinard \& Swain 2001, Vila-Gispert \& Moreno-Amich 2001, Lloret et al. 2002, Rätz \& Lloret 2003). The differences were thought to be related to food availability in temperate and tropical waters, where the best conditioned individuals inhabit the areas of high productivity (and food abundance), such as upwelling systems, coastal waters and areas influenced by river runoff. Differences in condition found in cold areas were attributed to water temperature and food supply, individuals being better conditioned at relatively warm and eutrophic locations where energy expenditure is lower and food is more abundant (Love 1974).

Post-spawners caught in the protected rocky coast were better conditioned than those from the unprotected rocky coast, which might reflect the better habitat quality of the marine reserve and/or the lack of intensive fishing in the reserve (only artisanal fishing is permitted). The effect of the reserve protection must be taken as an hypothesis. To assess the effect of any reserve protection on fish condition, future research should consider other marine reserves, years and species. Unfortunately, we do not have historic condition data (previous to the reserve establishment) to compare with the current data. Many studies have shown that marine protected areas enhance species richness, abundance, biomass and stock size structure (see Roberts \& Polunin 1991 for a review) and thus, have the potential to enhance fisheries in adjacent areas through export of biomass. Here, we suggest that protection may also affect fish condition positively. However, our investigations did not find any relationship between feeding potential and condition of fish, suggesting that food supply may not be the factor that determines habitat differences in the condition of white seabream; there may be other habitat characteristics, such as habitat structure or fishing stress. We also did not find any effect of protection on condition and feeding potential of spawning fish. It might be possible that spawning migrations dilute these relationships that otherwise exist during the post-spawning and juvenile phases. We also found that reproductive potential of males from the shallow areas of the marine reserve is higher than reproductive potential of males from deep areas of the marine reserve, which may indicate the better quality of shallow rocky habitats for the reproduction of Diplodus sargus. The lipid content in muscle of spawners, however, decreases with depth. This different bathymetric pattern in condition and GSI may suggest that fish with the highest reproductive potential inhabiting the shallow areas of the marine reserve are using more lipid reserves than fish from the deep areas, which have the lowest reproductive potential. Thus, the accuracy of condition indices as indicators of habitat quality during the spawning season is probably lower than in other seasons because of the relationship between energy reserves and the formation of gametes (Adams 1999, Morris \& Culkin 2000). In general, during the spawning period, energy reserves stored in the body are greatly diminished in order to supply energy for intensive generative synthesis. However, our investigations did not reveal any effect of condition on reproductive potential. Other studies also fail to establish a relationship between maternal condition and reproduction (Ouellet et al. 2001). Although we could not determine any effect of protection on reproductive potential of D. sargus, our data indicate that the percentage of adults in the population are higher in the rocky protected coast than in the rocky unprotected coast, which might reflect the effectiveness of reserves as areas to protect the spawning stock of this coastal species. Many studies have reported effects of marine reserve protection on spawning biomass of different marine species (e.g. review by Roberts \& Polunin 1991). A recent study showed that the proportion of ovigerous females of American lobster was larger within a marine reserve (Rowe 2002).

Apart from condition and reproductive potential, many authors have highlighted the importance of shallow rocky substrates as preferential habitat for settlement of certain fish species of commercial interest (mainly sparids; García-Rubíes \& Macpherson 1995, Harmelin-Vivien et al. 1995, Lenfant 1998, Guidetti 2000). In addition, rock habitats in deep water and submarine canyons are important habitats for some fishery species (Yoklavich et al. 1999, Brodeur 2001). Utilization of rocky habitats by numerous commercially, recreationally and ecologically important species across a wide geographic range most likely indicates their importance as 'essential fish habitats' for many species.

We also found effects of fish length, sex and reproductive status on some of the studied indices. For a given body weight, female spawners had bigger livers than male spawners and post-spawners of both sexes, indicating that females reach the reproduction season in better condition than males and also that sexual differences in liver size disappear after spawning. Female spawners of Diplodus sargus from the Cantabric Sea are also better conditioned than male spawners (Martínez-Pastor \& Villegas-Cuadros 1996). This is in contrast to many other species, where males are better conditioned than females because energy reserves are consumed more rapidly during maturation in females as their gonads are larger (Shulman \& Love 1999, Okuda 2001). Because liver size is usually related to lipid content, the liver size is indicative of lipid accumulation during favorable environmental conditions and utilization to support gonad development or 
adverse conditions (Love 1974, Adams 1999). Our results also reveal that post-spawners fed more actively than spawners, which might be linked to the reproductive cycle of the species or a seasonal effect (spawners were caught during spring, while postspawners were caught during summer). In many fish species, sexual maturity is accompanied by a sharp deceleration in growth; however, the body weight and condition continue to increase, usually at a higher rate (Shulman \& Love 1999). It is during this period, i.e. the change from juveniles to adults, that lipid content increases considerably (Kozlova \& Khotimchenko 2000). Usually, there is an accumulation of lipids and proteins with age and length (Hutchings et al. 1999, Okuda 2001). The lipid content of marine fish has also been found to increase during the feeding period and during gonad development (Adams 1999, Morris \& Culkin 2000). However, D. sargus, as well as other fish species (e.g. Payne et al. 1999), does not seem to follow these patterns because we did not find any difference in lipid content between juveniles and adults, nor any effect of length on lipid levels. Although our sampling was not designed to analyze spatial and bathymetric differences in the population structure of $D$. sargus, the results provide evidence that juveniles and postspawners inhabit shallow waters, while adults are found in deeper waters during the spawning season only. The differences in the mean lengths of fish sampled in each habitat are probably irrelevant because of the bias inherent to each sampling technique (spear fishing, gill net, trawling). The different sampling methods are not likely to affect, however, the condition indices used in this study or the reproductive potential.

The mobility of Diplodus sargus in the area of study is poorly known and therefore, it is not possible to state that the individuals captured in the different habitats are permanent inhabitants of the respective habitats. Instead, we must consider that fish have habitat preferences because in some habitats they have better conditions for growth, survival, etc (Minello 1999). In these preferred habitats, fish spend more time and many of their physiological parameters (e.g. growth, condition, feeding and reproductive potential) might be impacted by the characteristics of the habitat. Moreover, it should be emphasized, however, how condition of a mobile organism (fish), determined by integrating samples caught over several weeks, shows statistically detectable spatial patterns. Mobility makes the analyses performed conservative (i.e. significant spatial structures are only detected when they are actually present), because mobility would tend to break up any spatial pattern in a studied physiological parameter; in the same way, it tends to break up any abundance or length structures appearing in a fish assemblage (García-Charton \& Pérez Ruzafa 2001).
Taken together, our findings support the importance of rocky coastal habitats, especially the protected ones, for the condition and reproductive potential of white seabream in the Mediterranean Sea. We hypothesize that: (1) rocky areas may contribute significantly to the production of white seabream and are therefore potential 'essential fish habitats' for Diplodus sargus; and (2) marine reserves might be effective as a fisheries conservation tool for this species.

Acknowledgements. The authors would like to thank the staff of the Reserve Marine de Banyuls-Cerbère, the crew of RV 'Nereis' (CNRS), as well as F. Medale, A. Clavell, P. Lenfant, R. Lecomte, J. García-Charton, V. Riera, R. Galzin, N. Vert and $\mathrm{S}$. Rossi for suggestions and assistance in collection and analysis of data. We also thank 3 anonymous referees for their helpful comments on the manuscript. This research was funded by a Marie Curie post-doctoral fellowship from the EU (Quality of Life) to J.L. Additional funds were provided by the Diputació de Girona.

\section{LITERATURE CITED}

Able KW (1999) Measures of juvenile fish habitat quality: examples from a national estuarine research reserve. In: Benaka LR (ed) Proc Sea Grant Symp Fish Habitat: Essential fish habitat and rehabilitation. American Fisheries Society, Bethesda, MD, p 134-147

Adams SM (1999) Ecological role of lipids in the health and success of fish populations. In: Arts MT, Wainman BC (eds) Lipids in freshwater ecosystems. Springer-Verlag, New York, p 318

Barnes H, Blackstock J (1973) Estimation of lipids in marine animals and tissues: detailed investigation of the sulphophosphovanillin method for total lipids. J Exp Mar Biol Ecol 12:103-118

Bauchot ML, Hureau JC (1986) Sparidae. In: Whitehead PJP, Bauchot ML, Hureau JC, Nielsen J, Tortonese E (eds) Fishes of the north-eastern Atlantic and the Mediterranean, Vol 2. UNESCO, Paris, p 883-907

Benaka LR (1999) Summary of panel discussions and steps toward an agenda for habitat policy and science. In: Benaka LR (ed) Proc Sea Grant Symp Fish Habitat: Essential fish habitat and rehabilitation. American Fisheries Society, Bethesda, MD, p 455-459

Bertrand J, Gil de Sola L, Papaconstantinou K, Relini G, Souplet A (1999) Distribution of juveniles of some demersal species in the Northern Mediterranean. General Fisheries Commission for the Mediterranean (GFCM) working paper, Rome, 7-10 June 1999

Bolger T, Connolly PL (1989) The selection of suitable indices for the measurement and analysis of fish condition. J Fish Biol 34:171-182

Brodeur RD (2001) Habitat-specific distribution of Pacific ocean perch (Sebastes alutus) in Pribilof Canyon, Bering Sea. Cont Shelf Res 21:207-224

Chellappa S, Huntingford FA, Strang RH, Thomson RY (1989) Annual variation in energy reserves in male 3-spined stickleback, Gasterosteus aculeatus L. (Pisces, Gasterosteidae). J Fish Biol 35:275-286

Chouinard GA, Swain DP (2001) Bathymetric variation in condition and length-at-age of southern Gulf of St. Lawrence cod in September. ICES-CM 2001/V:06, p 1-14 
Cone RS (1989) The need to reconsider the use of condition indices in fishery science. Trans Am Fish Soc 118:510-514

Dalley EL, Anderson JT (1997) Age-dependent distribution of demersal juvenile Atlantic cod (Gadus morhua) in inshore/ offshore northeast Newfoundland. Can J Fish Aquat Sci 54(Suppl 1):168-176

De Silva SS, Gunasekera RM, Austin CM, Graeme A (1998) Habitat related variations in fatty acids of catadromous Galaxias maculatus. Aquat Living Resour 11:379-385

Dufour V, Jouvenel JY, Galzin R (1995) Study of a Mediterranean reef fish assemblage. Comparison of population distributions between depths in protected and unprotected areas over one decade. Aquat Living Resour 8: $17-25$

Fitzgerald JL, Knoechel R, Mullins CC (1998) Observations of temporal and spatial variability in density and relative condition factor of juvenile Atlantic salmon (Salmo salar) in the Harry's River Drainage System, insular Newfoundland, from 1987-1997. Canadian Stock Assessment Secretariat, Research Document 98/122, Ottawa, Ontario

Fogarty MJ (1999) Essential habitat, marine reserves and fishery management. Trends Ecol Evol 14:133-134

Folch J, Lees M, Sloane-Stanley GH (1957) A simple method for the isolation and purification of total lipids from animal tissues. J Biol Chem 226:497-509

Francis MP (1997) Condition cycles in juvenile Pagrus auratus. J Fish Biol 51:583-600

Francour P (1997) Fish assemblages of Posidonia oceanica beds at Port-Cros (France, northwestern Mediterranean): assessment of composition and long-term fluctuations by visual census. PSZN I: Mar Ecol 18:157-173

García-Charton JA, Pérez-Ruzafa A (2001) Spatial pattern and the habitat structure of a Mediterranean rocky reef fish local assemblage. Mar Biol 138:917-934

García-Rubies A, Macpherson E (1995) Substrate use and temporal pattern of recruitment in juvenile fishes of the Mediterranean littoral. Mar Biol 124:35-42

García-Rubíes A, Zabala M (1990) Effects of total fishing prohibition on the rocky fish assemblages of Medes Islands marine reserve. Sci Mar 54:317-328

Gordoa A, Molí B (1997) Age and growth of the sparids Diplodus vulgaris, $D$. sargus and $D$. annularis in adult populations and the differences in their juvenile growth patterns in the north-western Mediterranean Sea. Fish Res 33: 123-139

Grecay PA, Targett TE (1996) Spatial patterns in condition and feeding of juvenile weakfish in Delaware Bay. Trans Am Fish Soc 125:803-808

Griffiths D, Kirkwood RC (1995) Seasonal variation in growth, mortality and fat stores of roach and perch in Lough Neagh, Northern Ireland. J Fish Biol 47:537-554

Guderley H, Dutil JD, Pelletier D (1996) The physiological status of Atlantic cod, Gadus morhua, in the wild laboratory: estimates of growth rates under field conditions. Can J Fish Aquat Sci 53:550-557

Guénette S, Lauck T, Clarck C (1998) Marine reserves: from Beverton and Holt to the present. Rev Fish Biol Fish 8: 251-272

Guidetti P (2000) Differences among fish assemblages associated with nearshore Posidonia oceanica seagrass beds, rocky-algal reefs and unvegetated sand habitats in the Adriatic Sea. Estuar Coast Shelf Sci 50:515-529

Harmelin-Vivien M, Harmelin JG, Leboulleux V (1995) Microhabitat requirements for settlement of juvenile sparid fishes on Mediterranean rocky shores. Hydrobiologia 300/301:309-320

Hutchings JA, Pickle A, McGregor-Shaw CR, Poirier L (1999)
Influence of sex, body size, and reproduction on overwinter lipid depletion in brook trout. J Fish Biol 55: 1020-1028

Kaiser M, Rogers SI, Ellis JR (1999) Importance of benthic habitat complexity for demersal fish assemblages. In: Benaka LR (ed) Proc Sea Grant Symp Fish Habitat: essential fish habitat and rehabilitation. American Fisheries Society, Bethesda, MD, p 212-223

Kerrigan BA (1994) Post-settlement growth and body composition in relation to food availability in a juvenile tropical reef fish. Mar Ecol Prog Ser 111:7-15

Kjesbu OS, Kryvi H, Sundby S, Solemdal P (1992) Buoyancy variations in eggs of Atlantic cod (Gadus morhua) in relation to chorion thickness and egg size: theory and observations. J Fish Biol 41:581-599

Kozlova TA, Khotimchenko SV (2000) Lipids and fatty acids of 2 pelagic cottoid fishes (Comephorus spp.) endemic to Lake Baikal. Comp Biochem Physiol 126B:477-485

Krivobok MN, Tokareva GI (1972) Dynamics of weight variations of the body and individual organs of the Baltic cod during the maturation of gonads. Trudy VNIRO 85:45-55 (Translated from Russian by Trans Ser Fish Res Board Can, No. 2722, 1973), p 25-36

Lambert Y, Dutil JD (1997) Can simple condition indices be used to monitor and quantify seasonal changes in the energy reserves of Atlantic cod (Gadus morhua)? Can J Fish Aquat Sci 54(Suppl 1):104-112

Lambert Y, Dutil JD (2000) Energetic consequences of reproduction in Atlantic cod (Gadus morhua) in relation to spawning level of somatic energy reserves. Can J Fish Aquat Sci 57:815-825

Lee EM, Khan RA (2000) Length-weight-age relationships, food, and parasites of Atlantic cod (Gadus morhua) off coastal Labrador within NAFO Divisions $2 \mathrm{H}$ and $2 \mathrm{~J}-3 \mathrm{~K}$. Fish Res 45:65-72

Lenfant P (1998) Influences des paramètres démographiques sur la différentiation génétique intra-et inter-populations: le cas du poisson marin, Diplodus sargus (Linné, 1758). $\mathrm{PhD}$ thesis, Université Pierre et Marie Curie and EPHE, France

Lloret J, Rätz HJ (2000) Condition of cod (Gadus morhua) off Greenland during 1982-1998. Fish Res 48:79-86

Lloret J, Gil de Sola L, Souplet A, Galzin R (2002) Large-scale habitat variability in condition of demersal fishery species in the north-western Mediterranean. ICES J Mar Sci 59: $1215-1227$

Love RM (1974) The chemical biology of fishes. Academic Press, London

Man-Wai R, Quignard JP (1984) Les Sars Diplodus sargus (Linne, 1758) du Golfe de Lion: Croissance et caracteristiques des debarquements aux criees de Sete et du Graudu-Roi. Rev Trav Inst Peches Marit 46:173-194

Marshall CT, Frank KT (1999) The effect of interannual variation in growth and condition on haddock recruitment. Can J Fish Aquat Sci 56:347-355

Marshall CT, Yaragina NA, Lambert Y, Kjesbu O (1999) Total lipid energy as a proxy for total egg production by fish stocks. Nature 402:288-290

Martínez-Pastor M, Villegas-Cuadros L (1996) Edad, crecimiento y reproducción de Diplodus sargus Linnaeus, 1758 en aguas esturianas (norte de España). Bol Inst Esp Oceanogr 12:65-76

Micale V, Perdichizzi F, Santangelo G (1987) The gonadal cycle of captive white bream, Diplodus sargus (L.) J Fish Biol 31:435-440

Minello T (1999) Nekton densities in shallow estuarine habitats of Texas and Louisiana and the identification of essen- 
tial fish habitat. In: Benaka LR (ed) Proc Sea Grant Symp Fish Habitat: essential fish habitat and rehabilitation. American Fisheries Society, Bethesda, MD, p 43-75

Morris RJ, Culkin F (2000) Fish. In: Ackman RG (ed) Marine biogenic lipids, fats and oils, Vols I and II. CRC Press, Boca Raton, p 900

Okuda N (2001) The costs of reproduction to males and females of a paternal mouthbrooding cardinal fish Apogon notatus. J Fish Biol 58:776-787

Ouellet P, Lambert Y, Bérubé I (2001) Cod egg characteristics and viability in relation to low temperature and maternal nutritional condition. ICES J Mar Sci 58:672-686

Packer DB, Hoff T (1999) Life history, habitat parameters, and essential habitat of mid-Atlantic summer flounder. In: Benaka LR (ed) Proc Sea Grant Symp Fish Habitat: essential fish habitat and rehabilitation. American Fisheries Society, Bethesda, MD, p 76-92

Parrish RH, Mallicoate DL (1995) Variation in the condition factors of California pelagic fishes and associated environmental factors. Fish Oceanogr 4:171-190

Payne SA, Johnson BA, Otto R (1999) Proximate composition of some north-eastern Pacific forage fish species. Fish Oceanogr 8:159-177

Planes S, Hertel O, Jouvenel JY (1997) Analysis of condition and swimming performance in juveniles of white sea bream Diplodus vulgaris. J Mar Biol Assoc UK 77:913-916

Planes S, Galzin R, Garcia-Rubies A, Goñi R, Harmelin JG, Le Direach L, Lenfant P, Quetglas A (2000) Effects of marine protected areas on recruitment processes with special reference to Mediterranean littoral ecosystems. Environ Conserv 27:1-18

Rainuzzo JR, Reitan K, Olsen Y (1997) The significance of lipids at early stages of marine fish: a review. Aquaculture 155:103-115

Rätz HJ, Lloret J (2003) Variation in fish condition between Atlantic cod (Gadus morhua) stocks and implications for their management. Fish Res 60:369-380

Editorial responsibility: Otto Kinne (Editor), Oldendorf/Luhe, Germany
Roberts CM, Polunin NVC (1991) Are marine reserves effective in management of reef fisheries? Rev Fish Biol Fish 1:65-91

Ros JD, Romero J, Ballesteros E, Gili JM (1985) Diving in blue water. The benthos. In: Margalef R (ed) Key environment: Western Mediterranean. Pergamon Press, New York, p 233-295

Rosecchi E (1985) L'alimentation de Diplodus annularis, D. sargus, D. vulgaris et Sparus aurata dans le Golfe du Lion et les lagunes littorales. Rev Trav Inst Peches Marit 49: 125-141

Rowe S (2002) Population parameters of American lobster inside and outside no-take reserves in Bonavista Bay, Newfoundland. Fish Res 56:167-175

Sala E, Ballesteros E (1997) Partitioning of space and food resources by 3 fish of the genus Diplodus (Sparidae) in a Mediterranean rocky infralittoral ecosystem. Mar Ecol Prog Ser 152:273-283

Shulman GE, Love RM (1999) The biochemical ecology of marine fishes. In: Southward AJ, Tayler PA, Young CM (eds) Advances in marine ecology, Vol 36. Academic Press, London

Statsoft (1999) Statistica for Windows. StatSoft, Tulsa, OK

Underwood AJ (1998) Experiments in ecology: their logical design and interpretation using analysis of variance. Cambridge University Press, London

Vila-Gispert A, Moreno-Amich R (2001) Mass-length relationship of Mediterranean barbel as an indicator of environmental status in South-west European stream ecosystems. J Fish Biol 59:824-832

Yaragina NA, Marshall CT (2000) Trophic influences on interannual and seasonal variation in the liver condition index of Northeast Arctic cod (Gadus morhua). ICES J Mar Sci 57:42-55

Yoklavich MM, Greene HG, Cailliet GM, Sullivan DE, Lea RN, Love MS (1999) Habitat associations of deep-water rockfishes in a submarine canyon: an example of a natural refuge. Fish Bull 98:625-641

Submitted: July 2, 2002; Accepted: November 27, 2002

Proofs received from author(s): February 4, 2003 